\section{A Study of Students' Speech Acts in Organizational Education and Regeneration Program}

\author{
1 Harmita Sari \\ 2 Puspa Sari
}

12 Universitas Muhammadiyah Palopo, Indonesia

\begin{abstract}
This article aimed to describe, analyze, and explain the forms of speech acts of students after joining organizational education and regeneration program at Universitas Muhammadiyah Palopo. This research is a descriptive qualitative study that attempted to explain the speech acts that occur in the conversation. The subjects of this study were active students who had participated in the program. Data were taken from the results of observations, interviews, recording, and additional information in the field. The results of the research showed that the forms of the student speech act in the campus environment were (a) declarative, (b) imperative, and (c) interrogative.
\end{abstract}

\section{Keywords}

speech acts

education

organizational regeneration

\section{Ethical Lingua}

Vol. 7, No. 1, 2020

ISSN 2355-3448 (Print)

ISSN 2540-9190 (Online)

Corresponding Email

Harmita Sari

harmitasari93@gmail.com

Article's History

Submitted 30 March 2020

Revised 8 April 2020

Accepted 8 April 2020

DOI

10.30605/25409190.166

Copyright (๑) 2020

The Author(s)

This article is licensed under CC BY-NC-SA 4.0 License 


\section{A Study of Students' Speech Acts in Organizational Education and Regeneration Program}

Humans as individual creatures and at the same time as social beings need other people to meet their needs. The desire to fulfill the necessities of life causes humans to communicate in various situations. In this case, the role of language as a communication tool is very important. However, humans can also use other tools to communicate, and language is the best communication tool among other communication tools. In this communication, speech and speech acts occur. One form of speech that has got much attention is the act of an educator towards his/her students in interactions in the formal environment.

A speech act is a process of delivering a message or intention of the speaker to the interlocutor. Yule (1996: 6) defines speech acts as actions taken through utterance. The polite speech act (politeness) is the most appropriate tool used in communication, especially in the communication activities of lecturers or administrators of an organization that provides educational and regenerational messages to students in an organization or campus environment. Politeness is an interpersonal relationship system designed to facilitate interaction by minimizing the potential conflict and actual confrontation that is not limited to language. However, it also includes nonverbal or nonlinguistic behavior. Therefore, polite speaking needs to be made habituated by every lecturer, organization administrators while speaking to students, especially in providing education and training in the scope of organization, teaching-learning process, and in or outside campus environment.

Human beings have been instructed by Allah to speak in good and true manners, as in the quoted verse, which means "And say to My servants: 'Let them say the words that are better (true)"' (Al Qur'an). In this case, good or right sayings are undoubtedly inseparable from the situation of the speech that underlies the utterance. An autonomous organization of Muhammadiyah has some rights and obligations in the Muhammadiyah Association, one of which is maintaining the good name of the Muhammadiyah Association and fostering its members to be good citizens and members of the Muhammadiyah Association. One of the organizations in Universitas Muhammadiyah Palopo is Muhammadiyah Student Association (IMM) that is an Islamic student movement that engages in religious, community, and student affairs. The purpose of IMM is to try to create Islamic academicians who have a noble character in order to achieve the objectives of Muhammadiyah. Language is one of the important pillars in fostering well-qualified Muhammadiyah members. We respect people with our language, and they will also respect us with language, and so with a language we hate and will be hated by them. Good language can bring our nation to glory. Educators and cadres in the autonomous organization of Muhammadiyah should know and apply speech acts with the principles of politeness and politeness strategies in daily communication in order to create a harmonious condition and form the members of Muhammadiyah being polite in speaking.

Research in sociolinguistics and pragmatics has been widely carried out. For example, Arifin (2008) examined forms, functions, and strategies of students' speech acts in Singaraja while discussing in the classroom. Research in speech acts was also carried out by Saleh (2009), who stated that the representation of politeness in students' language was summarized in five main topics, namely: (1) the form; (2) the function; (3) the strategies; (4) explanation; and (5) 
implication of politeness in language. Damayanti (2014) studied that types of Kyai's speech acts use a lot of assertive illocutionary speech acts rather than directives because basically people of the religious community prefer to be invited rather than be governed and the most used types of speech acts are direct literal speech acts.

This research focuses on the speech acts of students who have received education and organizational training at Universitas Muhammadiyah Palopo. This study wants to find out whether the education and cadre training implemented by students can realize it in forms of polite speech acts (good). However, the overall results of previous studies still contribute to the completion of this study and at the same time as a comparative material.

\section{Method}

This research is qualitative descriptive, which is trying to explain in the form of words, descriptions. Bogdan \& Taylor (in Moleong, 1994: 43) say that qualitative research is a research procedure that produces descriptive data in the form of written or oral words from observable people and behavior.

Qualitative research is research that does not focus on quantity but instead emphasizes the quality of definition, concept, and characteristic of the object of research. This research was chosen with the consideration that the type of data needed is not to answer hypotheses but rather to describe speech acts conducted by postgraduate students in education and organizational regeneration. This study is called a qualitative study because of several reasons that are as follows: (1) research is carried out on a scientific setting, (2) humans as a key instrument. In this case, the researcher is a key instrument, (3) the study uses qualitative methods, (4) data analysis will be carried out inductively, (5) it is built from grounded theory, (6) is descriptive, (7) is more prioritizing the process than the results, (8) there are limitations that are determined by the focus of research, (9) built from designs that are temporary, (10) the results of the research will be negotiated and agreed on together (Basrowi \& Suwandi, 2006: 25-30).

The data of current research are speech acts of students who have received organizational education and regeneration program at Universitas Muhammadiyah Palopo. The data obtained is in the form of speech acts containing value both directly and indirectly. Subjects of this research are students who attended organizational education and regeneration program at Universitas Muhammadiyah Palopo. The number of informants is 15 people. The characteristics of the subject are: (a) students of Universitas Muhammadiyah Palopo; (b) members of Muhammadiyah organization; and (c) students who have joined organizational education and regeneration program. The key instrument in this study is the researcher. In addition, researchers use a tape recorder to record student speech. A tape recorder is also used to record researchers' interviews with students and lecturers. Other instruments used are field notes.

The techniques of data collection were carried out deductively by conducting observation, interview, recording, and note keeping. Qualitative descriptive analysis was used to analyze the data from the beginning to the end of the study. Data analysis was carried out during data collection and after data collection. This study used flow models from Miles \& Huberman's theories (1992: 15). The stages in this analysis include data reduction, data presentation, data verification, and drawing conclusions. 


\section{Results}

The results of research on students' speech acts in organizational education and regeneration program at University Muhammadiyah Palopo include declarative, imperative, and interrogative forms. The forms of speech acts are described as follows.

\section{Declarative Speech}

Conventionally, a declarative mode of speech in Indonesian is intended to inform the speech partner. However, in the daily use of speech in declarative mode, it can also be intended as an order, request, solicitation, and rejection. Besides, the declarative mode is intended to inform; it is also used to govern. In the context of interaction in the social environment, especially on campus, speech with a declarative mode is widely used by students. This is an effort to reach an understanding of communication as a speaker (Pn) with an interlocutor (Mt). If this understanding occurs, a harmonious relationship will be created based on the prevailing social norms in the daily life environment in campus and community.

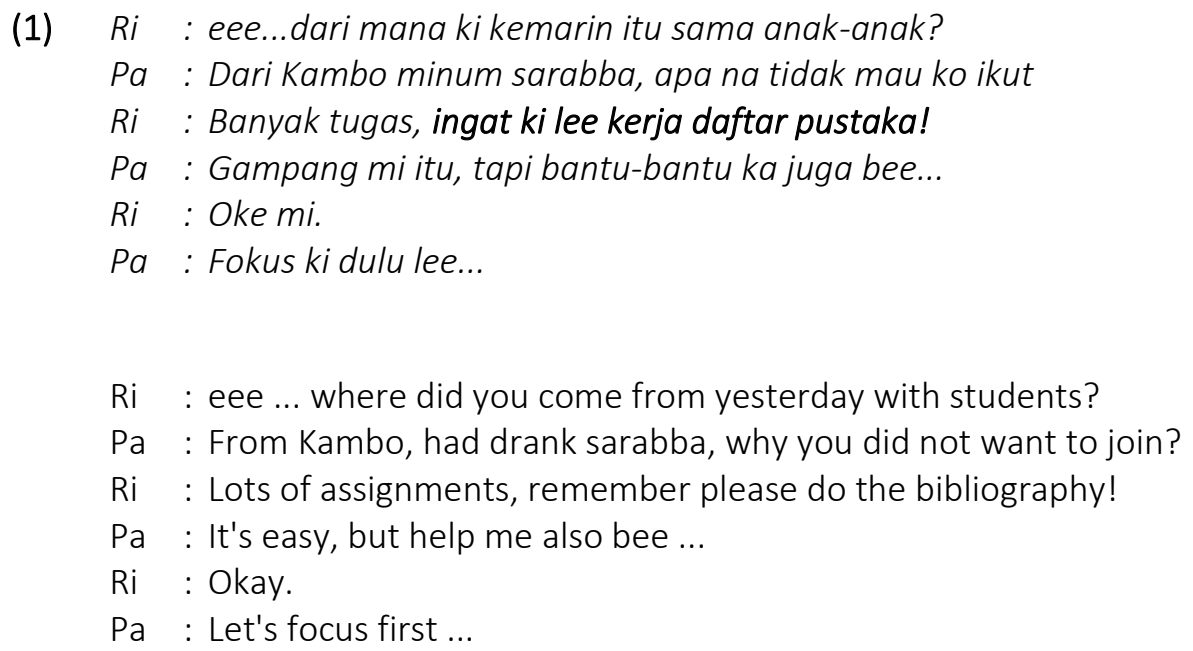

In data (1) it is a declarative speech with indirect literal meaning. Student (Ri) tries to inform his friend $(\mathrm{Pa})$ that one of the assignments of a course must be completed immediately, and students $(\mathrm{Ri})$ ask $(\mathrm{Pa})$ to make a bibliography. In fact, the speech intention of student $(\mathrm{Ri})$ is that his friend is expected immediately to complete his bibliography because there are some assignments, and they must be completed immediately. Furthermore, the student $(\mathrm{Pa})$ said the assignment is easy to do and asked the student ( $\mathrm{Ri})$ to help him. The student $(\mathrm{Pa})$ also asked that the focus be on completing college assignments by saying "Fokus ki dulu lee... (Focus first lee .."). By inviting to focus on doing the assignment is an approval response to the student's order (Ri) expressed through speech in a declarative mode.

Student' (Ri) Speeches in the data (1) are not literal. Basically, the purpose of student' (Ri) speech is to order the student $(\mathrm{Pa})$ to complete the assignment as soon as possible namely to make a bibliography. However, in the speech of student (Ri) use sentences in a declarative mode as if they were merely informing. In a pragmatic review of student's (Ri) speech, it has a further purpose that is to rule or order. These utterances are polite. In the speech, a variety of informal Indonesian languages are used. This is indicated by the use of informal diction using the enclosure of the Palopo language or dialect, namely $-k i$ and -lee '. The $-k i$ enclitic functions as a marker that politely states property, while the use of -lee 'as a reinforcement or affirmation commands gently. In the speech of students $(\mathrm{Pa})$ use the diction -bee ... with 
the sentence "bantu ka juga bee (help me also ..."), which functions as a formal confirmation, or ask for help politely. Thus, it can be said that the speech of seventh-semester students (7) has been polite in terms of ordering or ordering his friend/student ( $\mathrm{Pa})$ to work on college assignments immediately.

In the campus environment, both students and lecturers sometimes use a declarative mode of speech to ban. The prohibiting speeches are used by seventh-semester students (7) to junior juniors of the fifth semester (5) when they are busy telling stories in the cafeteria of Universitas Muhammadiyah Palopo. Then the senior or seventh semester student (7) looks at his junior who is telling about his friend's problem. This can be seen in the following statement.

(2) Far : ee.. dek jangan ki cerita orang kalau belum pasti kebenarannya

Tau : aahh.. tidak ji kak, tapi memang begitu kebenaranya

Far : cocokmi tapi diam-diam ki saja, takutnya ada orang yang tidak senang dengan cerita ta'. Kemudian, na sampaikan lagi ke orang lain

Tau : lyee kak, hehehehee

Far : Besok, jangan ki lupa nah, datang rapat di sekret, lihat-lihat ki saja di group informasinya

Tau : Siap kanda.

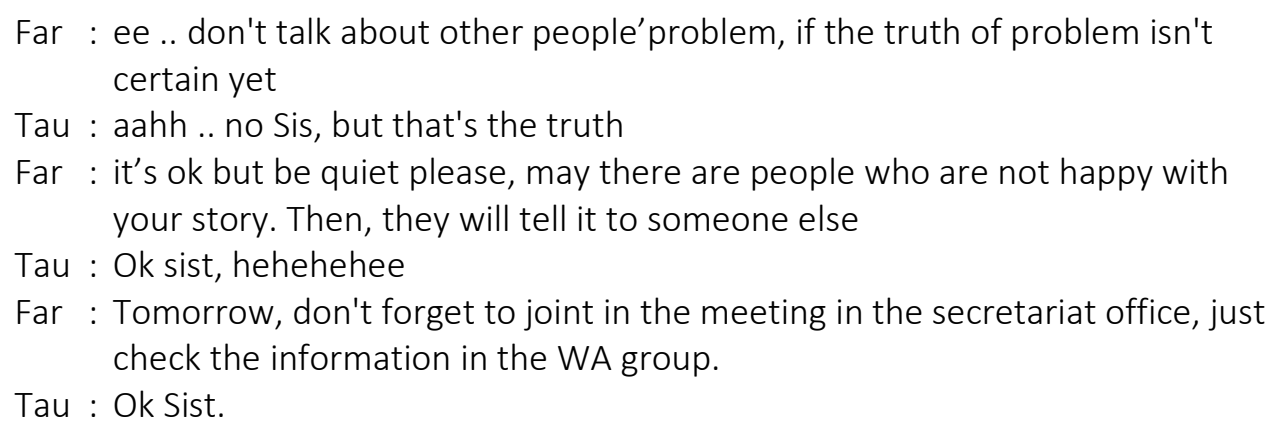

In the statement (2) above, the student (Far) reprimands his junior so as not to tell about things that are not yet clear. Junior responded by saying "aahh.. tidak ji kak (ahhh...no Sis, but that's true". His seniors again rebuked in a subtle way by reemphasizing, if the conveyed thing is heard by someone and she/he informs again to others, it can spread the news widely. It will disrupt the lives of those people. Junior (Tau) immediately responded by saying, "lyee sis, hehehehee" (Yes Sist hehehehe). It means that it will not continue the story. Senior student (Far) again ordered his juniors to join in the meeting, and the junior student (Tau) was ready to come.

\section{Imperative Speech}

There is also an imperative mode of students' speeches. The utterances are used by students to ask, order, forbid, order, and warn. The following speeches are used to state the function formulated by using Indonesian with varied linguistic. The existence of speech with imperative mode shows the fairness and politeness in speech. In the campus environment, the speech of students with an imperative mode is reasonable and polite. The speech is used to convey the request of seniors (students) to juniors, staff, peers, lecturers, and anyone in the campus environment. 
The use of speech tends to show the creation of harmonious relationships and the achievement of mutual understanding-for example, speech delivered by a senior (student) to his lecturer. Students ask permission to the lecturer directly, so that permission is given not to join the course, because she wants to accompany their mother to the hospital. The lecturer grants the student's request, the speech that is sometimes used is the imperative sentence in the form of a request. This can be seen in the following speech data (3).
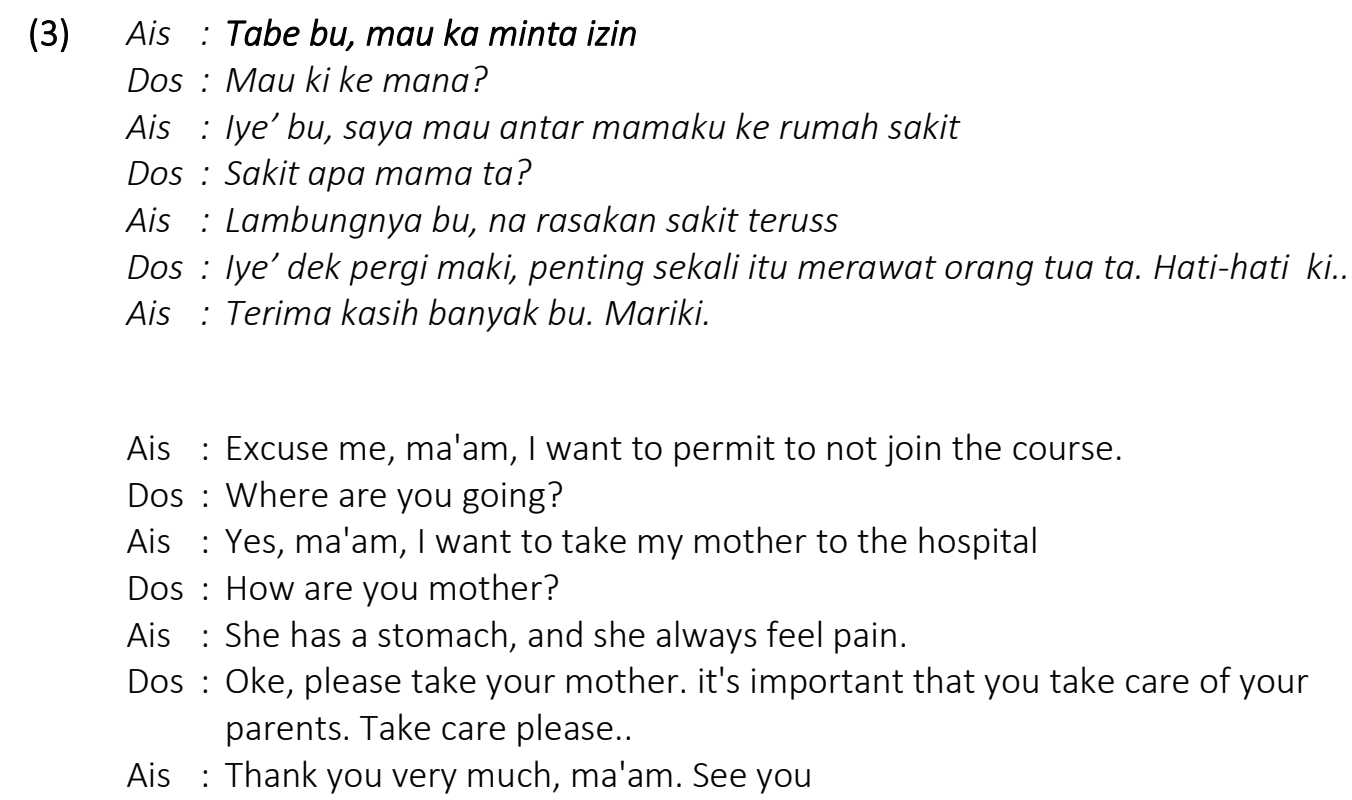

The students' speech (Ais) in the data (3) above is a direct imperative mode that have a literal meaning. This is intended to ask directly. In this case the student (Ais) uses the speech to ask permission from his lecturer, by saying "Tabe bu, mau ka min ta izin" (Excuse me maam, I want permission"). The language used by students (AIS) is formulated with non-formal Indonesian. This is marked by linguistic variations in politeness in the form of variants of action. This variant is also a sign of respect, the use of tabe and iye diction is a sign of politeness, tabe means sorry and iye' means yes (very polite diction).

The imperative speech is sometimes used to prohibit. However, this does not have the potential to cause a conflict. The speech continues to facilitate harmonious relations, as well as by creating a shared understanding between the speaker and the interlocutor. This can be seen in the speech of a senior student to his friend when asking permission to not join in the meeting until it is up. The senior student uses prohibited speech because their friends won't join in the meeting until it's not accepted. This can be seen in the following data (4).

(4) Lin : Man, tidak bisa ka nanti ikut rapat sampai selesai

Man: Kenapa?

Lin : Ada janjianku sama teman di lapangan pancasila

Man: Jangan ki begitu, harus ki hadiri rapat sampai selesai, ini rapat terakhir ta

Lin : Awwee...susahnya mi itu

Man: lye' harus ki ikut apalagi kita sekretaris panitia. Hehehehe, lupakan mi dulu janjian yang lain say, jadikan acara ta ini sebagai priorotas, biar nanti berjalan dengan lancar, oke say.

Lin : Hmmm...pasrah mika lagi, kalau begini. 


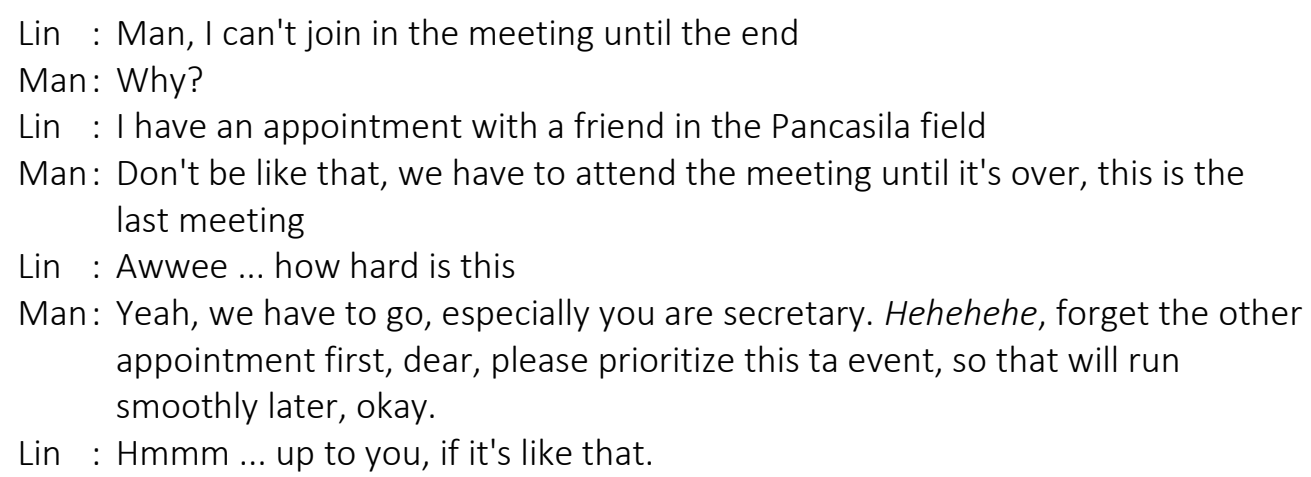

Student's (Man) speech as in data (4) is a direct literal declarative mode. The student (Man) uses the speech to respond to his student friend (Lin) who asks for permission not to attend the meeting until it is over. The statement was stated by the student (Man) to convey a ban in accordance with his status and authority as chair of the committee in the campus organizational environment. Based on differences in positions in a committee between students (Man) as the chairman and students (Lin) as members of the secretary, therefore, students (Man) have the authority to prohibit. The use of the speech is still considered reasonable. The speech is polite. In this case, the speech uses informal Indonesian. This is indicated by the use of $-m i$ at the end of the diction used. By using Indonesian that has such characteristics, the speech seems to smooth the prohibition. However, because it was delivered in a less firm tone, the speech still smoothed the prohibition of the student (Man). The command / prohibition was conveyed by superiors to subordinates who were explaining. Therefore, the declarative mode of speech used by student (Man) is quite polite. That is, the use of the speech is still pleasing to the interlocutor so that the speech partner can accept the prohibition of the student (Man) gladly.

\section{Interrogative Speech}

The interrogative mode of speech is used by students to urge, convince, forbid, remind, joke, order, evade, agree, and prove. Students speak each other in the campus environment sometimes use an interrogative mode to express urgency. For example, the speech of a senior student to his junior student is urged to move quickly in preparation for the inauguration of the IMM board. These are as follow:

(5) Arm: Tabe kak, harus mika dibagikan ini undangan ke mantan pengurus IMM

Fah : Awweee, kenapa na lambat sekali

Arm : Iye, sementara dibuat mi

Fah : Lambat sekali panitia bergerak

Arm : Sibuk semua kak

Fah : Harus kau bagikan besok, harus na dapat semua itu undangan

Arm : lye kak, berpencar ki besok.

Arm : Excuse me, Sis, I have to give these invitations to the former IMM board

Fah : Awweee, why do you move very slowly?

Arm : Sorry, they are is being completed.

Fah : The committees move slowly.

Arm : They are busy, Sis

Fah : You have to share them tomorrow; you have to get all those invitations

Arm : Yah, Sis, we will spead tomorrow. 
Speeches are in the data list (5) are interrogative mode speech indirectly that means they are not literal. The speech begins with the speech of a junior student (Arm) who asks the invitation to his senior. The senior student (Fah) immediately responded with high voice intonation with the sentence "Awweee, kenapa na lambat sekali (Awweee, why don't you move very slowly"). This speech is a picture of disappointment; students (Fah) hoped that the invitation had been distributed. In the next statement, students (Fah) urged student (Arm) including the committee team to immediately distribute invitations, with the sentence "Harus kau bagikan besok, harus na dapat semua itu undangan" ("You have to share tomorrow, you have to get all those invitations").

The use of the word "must", which is mandatory, students (Arm) are urged by their seniors to immediately distribute the invitation; it is a compulsion that must be implemented. The student (Arm) responded well, answering with the phrase "lye kak, berpencar ki besok." "Yah Sist, we will speard tomorrow"). In the data statement (5) above it is a natural speech to be used to urge. This means that student (Fah) as seniors who are also part of the organization on campus have shown their concern and concern for students (Arm), the activity committee, and their attention to the inauguration of the IMM management. Senior students paying attention to juniors or organizations on campus is one of the tasks and responsibilities of a senior. Speech used is quite reasonable and polite. In this case, the speech uses informal Indonesian language which is marked by the use of the diction "Awweee" meaning disappointment that confirms that it must be done immediately and do not do slowly for the smooth running of an event. Likewise, the attitude of junior student who responds well, answering with the sentence " lye kak, berpencar ki besok." ("Yah Sist, we will spread tomorrow"). Such speech has an opportunity to create a harmonious situation, and can reduce the opportunity for conflict, and to make it easier to reach mutual understanding.

Speech data (5) can form the competent attitude of junior students (Arm). The capable attitude is one of the attitudes that must be possessed by humans, especially students who have been given the mandate to carry out or succeed an activity. Senior student's speeches (Fah) have been able to shape their junior skills. This must be done by a student and can be an individual control of students so that they can carry out their duties properly and quickly.

The students' speech sometimes has an interrogative mode to declare an agreement. This is reasonable and polite if it was done by students towards one of the staff to create harmonious relationships and achieve mutual understanding. Such speech was delivered by students and one of the staff, when students wanted to help campus staff complete the tasks assigned to the staff. This can be seen in the following sample speech (6).

(6) Nur : Apa lagi namanya ini kak?

Staf : Bilang saja pelubang kertas

Nur : Jadi kususun mi di sini?

Staf : Asiapp

Nur : Hehehee pop ice saja

Nur: What is it, Sis?

Staff: Just say the hole punch

Nur : So I arranged them here?

Staff: Asiapp

Nur: Hehehee pop ice only 
Speech (6) in the conversation is in the form of interrogative speech having direct literal meaning. The student (Nur) uses these utterances in the form of questions with the intention of asking about items that are nearby, while helping staff compile files. This is normal for students (Nur) in accordance with their status as students who want to help staff, so that they use tools according to their functions.

The speech uses informal Indonesian language marked by the use of the diction "Jadi, kususun mi di sini?" ("So, I arranged them here?"). In addition, it is marked by the use of particles from the Palopo -mi dialect, which means it is composed now. In the context of the campus environment, student speech (Nur) can create harmonious relationships and achieve mutual understanding. In terms of the informal atmosphere, it is very supportive of using polite diction from Palopo area. Speech in data (6) is a form of responding to the speech partner which shows an agreement to realize the expectations of the speech partner. Therefore, this speech cannot cause conflict. The speech is looking for agreement and does not force the speech partner to agree with the speaker.

\section{Discussion}

Based on the data analysis that has been presented, research findings are students' speech acts in organizational education and regeneration program at Universitas Muhammadiyah Palopo in conversations in campus that include declarative, imperative, and interrogative forms. The three sentence modes can be realized through the form of politeness, both using linguistic politeness markers and through socio-pragmatic markers.

The choice of speech acts can be based on simple structural separations that are easily known and understood, namely declarative, imperative, and interrogative forms (Yule, 1996: 95). Lapoliwa in Nadar (2001: 71) says that sentences in Indonesian can be seen from the communicative aspect. Pragmatic classification of sentence forms can be stated that statement sentences are used by the speaker to provide information to the listener. The command sentence is used by the speaker to express commands, orders, invitations, wishes, hopes, or prohibitions to do something to the listener. The question sentence is used to request information from the listener.

The students' speech acts in organizational education and regeneration program at Universitas Muhammadiyah Palopo show that students' conversations on campus environment in the form of declarative speech are used to (1) declare orders, (2) refuse, (3) promise, (4) require, and (5) prohibit. In conversation between students and the community in the campus environment, the form of directives appears in the role of students as people who have high rights and obligations towards the campus environment.

The use of speech forms in the declarative mode is quite reasonable and polite in the conversation of students with the community in the campus environment. The speech is realized through the use of informal Indonesian language. This is indicated by the use of (1) informal variations in the form of the use of words mariki, masussa, anu, lupai, bilang, tebe, maini, (2) the use of kinship greeting word (kinship) for example the use of words kak and dek which means brother and sister, (3) the use of particles -e, -ke, -ko, -ji, -le, -na, -be, -ki etc. (4) the use of affirmative responses using the words iye, ya (yes), and (5) is conveyed according to status as a student in the campus environment. 
Speeches used by students in conveying declarative forms are generally formulated with informal markers with various linguistic markers. The use of this declarative form by students who have followed the training in organization in particular, with these characteristics tends to be oriented towards the reasonableness and politeness. In this case the use of speech is generally quite reasonable and polite based on social and cultural norms that apply in interactions in the campus environment.

The social interaction of politeness aspect naturally matches the culture in community. Determination of general principles are different in social interactions of a particular culture. Some of these general principles include being wise, generous, humble, sympathetic, towards others. Participants in an interaction are generally aware that such norms and principles exist in the community. However, in politeness it is stated that a more specific thing is known as a facial concept. This face refers to a person's social and emotional meaning. This is an interaction that influences politeness (Yule, 1996: 104).

In a social interaction people sometimes behave as if their hopes relating to the good name of community or their face will be respected. This happens if the speaker says something that can reduce a threat to the person that is also commonly called an act of saving the face. This is in line with Nadar (2001: 41) who says that the act of saving the face of interlocutor is an act of politeness that is principally intended to reduce an unpleasant effect on the face of interlocutor (opposing speaker) both in positive and negative faces. Politeness aimed at a positive face (positive politeness) while politeness directed at the negative face of the interlocutor is called negative politeness (negative politeness). So that it can form negative and positive politeness.

Some of the language levels between the different speakers in different social levels are manifested in the selection of words or the morphological system of certain words. Manners in language are carried out by someone because they are driven by the respect for the person being addressed. In this case, the effect of honorifics or the use of honorable language forms plays an important role.

\section{Conclusion}

Based on the problem, objectives, and results of analysis and discussion, it can be concluded that forms of students' speech acts in organizational education and regeneration program at Universitas Muhammadiyah Palopo are (a) declarative speech, namely in the form of speech telling or commanding, and prohibiting, ( b) imperative speech that is in the form of demand speech, the form of this student's speech can form creative characters. The prohibiting speech can form a discipline character. The commanding speech is a helpful character building through speech. The commemorating speech forms a polite character. (c) Interrogative Speech, namely in the form of urging speech (urging), forming students' competency. Based on the results, the evasive speech can form an honest attitude. The agreement speech forms a friendship and communicative situation in the campus environment, for example students' speaking to one of the staff in campus.

\section{Acknowledgment}

N/A 


\section{References}

Arifin, A. (2008). Representasi Tindak Tutur Siswa dalam Percakapan di Kelas. Malang: Universitas Negeri Malang.

Basrowi, B. \& Suwandi, S. (2006). Memahami Penelitian Kualitatif. Jakarta: PT. RinekaCipta.

Damayanti, A. D. (2014). Tindak Tutur Kiai Mengenai Syarah (Penjelasan) Kitab Al Hikam Dan Tafsir Al-Qur'an Dalam Pengajian. Jurnal Bahasa \& Sastra, 14 (1). 58-70.

Departemen Agama RI. (2008). Al-Qur'an dan terjemahannya. Bandung: Diponegoro.

Miles, \& Huberman. (1992). Analisis Data Kualitatif. (Translated by Tjejep Rohendi Rohiddari, Qualitative Data Analysis). Jakarta: Universitas Indonesia Press.

Moleong, L. J. (1994). Metodologi Penelitian Kualitatif. Bandung: Remaja Rosdakarya.

Nadar, F. X. (2001). Pragmatik \& Penelitian Pragmatik. Yogyakarta: Graha IImu.

Saleh, S. (2009). Representasi Kesantunan Berbahasa Mahasiswa dalam Wacana Akademik: Kajian Etnografi Komunikasi di Kampus Universitas Negeri Makassar. Malang: Universitas Negeri Malang.

Yule, G. (1996). Pragmatik. Translated by Fajar Wahyuni, Pragmatics. Yogyakarta: Pustaka Pelajar. 